\title{
Improving Job Performance: Workplace Learning is the First Step
}

\author{
Younes Daryoush \\ Department of Professional Development and Continuing Education Faculty of Educational Studies, Universiti Putra Malaysia \\ Tel: 60-17-8881068 E-mail: younes.daryoush91@gmail.com \\ Abu Daud Silong \\ Department of Professional Development and Continuing Education Faculty of Educational Studies, Universiti Putra Malaysia \\ Tel: 60-3-89468250 E-mail: adsz@ace.upm.edu.my \\ Zohara Omar \\ Department of Professional Development and Continuing Education Faculty of Educational Studies, Universiti Putra Malaysia \\ Tel: 60-3-89467911 E-mail: zoharah@educ.upm.edu.my
}

Jamilah Othman

Dept of Professional Development and Continuing Education, Universiti Putra Malaysia

Tel: 60-3-8946-6000 E-mail: jamilah@educ.upm.edu.my

Received: 17-05- 2013

doi:10.7575/aiac.ijels.v.1n.1p.100
Accepted: 27-06- 2013

URL: http://dx.doi.org/10.7575/aiac.ijels.v.1n.1p.100

Published: 01-07- 2013

\begin{abstract}
The present study aims to contribute new knowledge to the existing literature on workplace learning and job performance. Particularly, the study analyzes contemporary literature on workplace learning and job performance, specifically formal and informal learning as well as employee task performance and contextual performance. The study hypothesized that informal, incidental and formal workplace learning have direct positive significant relationships with employee task and contextual performance.

Keywords: task performance, contextual performance, informal workplace learning, incidental workplace learning, formal workplace learning
\end{abstract}

\section{Introduction}

How can job performance improve without learning?

Learning perspective in human resource development supports that learning is the only way to develop human resource. The competition among organizations in the current century developed to gain competitive advantage and resultant success. Workplace learning is one of the tools managers can use to gain a competitive advantage of organizations (Cromwell \& Kolb, 2004; Heilmann, 2007; Rothwell, 2002). Nowadays, organizations are knowledge-based; hence, employees have to constantly update their knowledge and skills (Kyndt, Dochy, Michielsen, \& Moeyaert, 2009; Park, 2009). Organizations have identified their human capital as the key source of sustainable development (R. Rowden, 2007).

Jacobs and Washington (2003), identified employee competence in a position as an important factor in all types of organizations. Since changing workplace environment has affected the workplace, improving significantly employees' skills and knowledge to meet the rapidly environment changes has become a significant issue in organizational development (R. L. Jacobs \& Park, 2009; Park, 2009; Patterson, et al., 2005; R. Rowden, 2007; Smith \& Hayton, 1999). The current study focuses on the employees' job performance.

First, we review the literatures on job performance and discuss two types of performance emphasized in previous research. Second, we explore past studies on workplace learning by considering the perspective of typology. In the next section, we identify two job performance dimensions that correspond to three types of workplace learning. Third, we present a model of relationships among these five variables. In this model, workplace learning not only facilitates members' well being and organization's viability, but it also integrates individual members' task focused contributions. We also briefly discuss two issues that may need to be considered when staffing organizations; that is, task type and phase of career development.

\section{What is Job Performance?}

Performance has been defined based on behaviors or activities that are associated with the goals of an organization (Motowildo, Borman, \& Schmit, 1997). The mission of organization and judgments of the behaviors made by supervisor are often used to identify these goals. Moreover, job performance is the action or behavior itself and not the 
result of actions or a consequence (J. P Campbell, McCloy, Oppler, \& Sager, 1993). What we know about job performance is based largely on previous studies. These studies considered job performance as result of behavior. For example, Barrie and Pace (1998) suggested that organizations can improve job performance through controlling employees' behaviors.

The key problem with this idea is that if we studied job performance as result of behavior, this performance approach would be "mechanistic" (Bierema, 2000). Gilbert (1978), who noted that we should focus on other factors rather than just behavior to explain performance, conducted preliminary work on job performance. Two reasons for working on job performance are identified: (1) the term performance implies system effectiveness and individual development, and (2) the behavioral perspective emphasizes changing system based on employees' work but without considering employees' attitude (Gilbert, 1978).

Many scholars have argued about the variables that can be used to measure employees' results. "Can the results and/or outcomes that aid the organization in reaching its goal be measured in terms of profit or fulfilling the mission?" Researchers have considered this important question because when organizations plan long-term development or effectiveness, they should measure the performance by accounting for other factors in addition to the results of behaviors. Both attitude and behavior should be considered in measuring the performance (Jones, 2006, p.23).

Campbell et al. (1990) presented eight factors of the job performance model based on research that attempted to identify measures of job performance that would be applicable for all jobs. Task behaviors involve technical activities that reflect an individual's effort as part of a job. They are the "technical core" tasks that delineate one job from another. The second type of behaviors is the one that an individual is required to complete, and it does not relate only to a specific job. For example, "task specific" behavior of sales people would be presenting a product to a customer. A "nontask specific" behavior of a sales person might involve advising new employees. An employee's performance might be assessed in terms of effort in unusual conditions. This factor indicates the degree to which people commit themselves to job tasks (J. P Campbell, et al., 1993).

Many jobs consider supervisory or leadership factor. The individual should be responsible for rewards and punishments more than ordinary tasks (J.P. Campbell, et al., 1990). Managerial task would be setting goals or responding to external needs to assist a team in achieving its goals (J. P Campbell, et al., 1993).

Borman and Motowidlo (1993) determined two kinds of performance: contextual performance and task performance. Task performance is defined as produce materials or providing services, such as expertise in job-related tasks. Task performance also involves activities that support the technical part and service of a firm or an organization, such as coordinating and planning (W.C. Borman \& Motowidlo, 1993). Contextual performance is defined as the degree to which organizational context contributes to organizational effectiveness (Motowidlo, 2003). For instance, increasing individuals' readiness to perform with valuable behaviors and taking initiative for solving problem in organization context can be used to measure contextual performance.

Similarly, a previous research argued that task habits, task skills, and task knowledge increase the likelihood of performing behavioral elements of job performance, such as achieving goals (Sonnentag \& Frese, 2002). On the other hand, contextual skills and knowledge affect contextual performance by enhancing behaviors that help and support social and organizational context or by increasing values and psychological climate (Reio Jr, 1997).

Based on previous research, performance concept is realized with several basic assumptions. The first assumption is that the performance is measured by behavior rather than the outcomes or results. That explains why an employee cannot control some aspects of the outcome. Therefore, it may appear that the employee did not fulfill all tasks to meet organization goals. The second assumption is that behavior performance is periodic. For instance, one can start a task at a certain time and finish it at another time. The third assumption suggests that performance is context based. Contextual performance results from behaviors that support the workplace environment in which tasks are performed, for example, helping other colleagues and cooperation (W.C. Borman \& Motowidlo, 1997; Rotundo \& Sackett, 2002).

Differences between the task and contextual performance depend on employees' abilities and personalities. "Task performance" is influenced by individual ability while "contextual performance" is influenced by personality (W.C. Borman \& Motowidlo, 1993, 1997; W.C. Borman, White, Pulakos, \& Oppler, 1991).

The argument of individual differences between contextual and task performance come out is that the associations of specific dimensions of performance and specific individual differences. On the one hand, individual differences affect task performance while on the other hand, differences in personality traits cause differences in contextual performance.

\subsection{Task Performance}

Task performance can be defined as the effectiveness with which job incumbents carry out activities that contribute to the organization's "technical core" either directly by executing a part of its technical process or indirectly by providing it with needed materials or services (W.C. Borman \& Motowidlo, 1993). Furthermore, another definition of task performance is the ability to meet expectations and demonstrate competency and expertise. Those expectations are directly associated with the organization's technical core achieved by conducting, servicing, and maintaining its technical requirements (Harrison, Newman, \& Roth, 2006).

In the past, researchers defined task performance as the "role performance" (Katz \& Kahn, 1978), "job role" (Welbourne, Johnson, \& Erez, 1998), or task performance as the fulfillment of duties and responsibilities related to a given job (Murphy \& Shiarella, 1997). Campbell (1990) categorized the terms job-specific and non-job specific task 
proficiency to explain activities and actions conducted to fulfill technical tasks. Borman and Motowidlo (1993) defined task performance as a behavior that is formally recognized as part of the job that contributes to the organization's technical core. Borman and Brush (1993) used the term technical activities to describe behaviors that demonstrate technical proficiency. Considering task performance, job knowledge and ability play a significant role in technical competence of jobs (W.C. Borman, et al., 1991; Hunter, 1986; Schmidt, Hunter, Outerbridge, \& Goff, 1988).

\subsection{Contextual Performance}

Other activities that are not necessarily task-related but that contribute to the organization in a positive way are included in contextual performance area. Demonstrating effort and facilitating peer and team performance (J.P. Campbell, et al., 1990), altruism, conscientiousness (D.W. Organ, Podsakoff, \& MacKenzie, 2006), organizational role (Welbourne, et al., 1998), and affiliative-promotive behavior (Van Dyne \& LePine, 1998) are behaviors that help and support peers. Interpersonal relations (Murphy \& Shiarella, 1997), interpersonal dealings and communication (W. C Borman \& Brush, 1993), and courtesy (Dennis W Organ, 1988) describe behaviors related to cooperating, communicating, and exchanging job-related information. Civic virtue (Dennis W Organ, 1988), constructive suggestions along with spreading goodwill (George \& Brief, 1992) and endorsing, supporting, and defending organizational objectives (W.C. Borman \& Motowidlo, 1993) describe behaviors related to participating in the political life of the organization and promoting a favorable organizational image.

Taxonomy of contextual performance based on Coleman and Borman (2000) comprises three dimensions. They are interpersonal citizenship performance (behavior benefiting individual organization members, such as cooperation, encouraging the colleagues); job conscientiousness (looking for challenging assignment), and organizational citizenship performance (courtesy) (W.C. Borman, et al., 2001).

\section{Workplace Learning}

Workplace learning is defined as 'a process in which individuals, teams, and organizations obtained knowledge, skills, and attitudes according to their continuous interactions with each other or within the context of solving business problems and improving performance' (S.-Y. Moon \& S.-I. Na, 2009, p.328).

While various definitions of the term workplace learning have been suggested, workplace learning is a collaborative process occurring in a social context (Brown \& Duguid, 1991). It emphasizes learning rather than formal training (S. Y. Moon \& S. I. Na, 2009). Workplace learning has three components. First, workplace learning consists of both learning activities taking place in the workplace and learners-oriented empirical and daily learning activities (Marsick, 1987). Second, the workplace is a learning field which is learning in works setting (Matthews, 1999). Third, interpersonal interaction and context influences create workplace learning by focusing on social aspects such as shared mutual perceptions (Illeris, 2004).

Several researchers studied workplace learning but in different meanings and forms, such as training (formal learning), work-related learning, self-directed learning, and learning at work. They showed that workplace learning is the key subject.

In fact, different researchers have used the expression 'workplace learning' to mean very different things. For instance, Watkins and Marsick (1992) claimed that there are different forms of workplace learning, such as informal, incidental, and formal learning. They concentrated to informal and incidental learning rather than formal learning (Park, 2009). Formal learning is defined as individually planned events to train people on how to do specific jobs. It is usually offered by institutions, and it is classroom based. Informal learning may happen in training institutions, but it "is usually not classroom-based or highly structured; the control of the learning is in the hands of the learner, not determined by the organization" (Park, 2009).

Workplace learning is measured by identifying environmental factors that facilitate workplace learning (Rothwell, 2002) or by recognizing the key elements of workplace learning (R. W. Rowden, 2002). Workplace learning has various meanings and forms. Several terms include work and learning: workplace learning, training, learning at work, learning in work, work-related work, and lifelong learning (Park, 2009).

Colley et al. (2003) studied workplace learning from a similar perspective but they tried to categorize it based on different characteristics of formal and informal learning. They suggested that these types of learning can overlap many times but this category can lead us for knowing the nature of learning in workplace considering position, environment, benefits, and direction. They emphasized that based on this framework, researchers can analyze and understand various types of workplace learning (Colley, et al., 2003; Park, 2009).

On the other hand, Clarke (2005) explained workplace learning as formal learning, group on-the-job learning, and independent on-the-job learning (Park, 2009). The key problem with this explanation is that other types of workplace learning are ignored. It seems that informal learning environments show vague status in terms of learning. Informal and incidental learning are shaped by the conditions and environment of work practices (Billett, 2001).

\subsection{Informal Workplace Learning}

The term, "Work place learning", has been used to explain different situations. Watkins and Marsick (1992) identified three types of workplace learning including formal, informal, and incidental. Putting emphasis on the informal and incidental learning, they gave less significance to formal learning. Formal learning contains individually planned incidents to train individuals regarding how to execute a particular given task. It is also structured and financially supported by an institution. On the contrary, informal learning is implemented in training institutes, but it is not highly 
structured or performed in classroom. Furthermore, learners are not given a specific plan for learning by the institute but they autonomously undertake to learn a task(Park, 2009).

Enos et al. (2003) studied proficiency of manager mentioned trial and error as one type of informal learning activity that can improve knowledge, contrary to training activity and planned activity as formal learning. Correspondingly, Leslie et al. (1998) explained that following goals and objectives of organization by employee can cause informal learning; hence, informal learning is very important for organizational achievement (Leslie, Aring, \& Brand, 1998).

\subsection{Incidental Workplace Learning}

Watkins and Marsick (1992) also defined incidental learning as an unintended activity, such as trial-and-error, experimentation, and interpersonal interaction, arguing that informal and incidental learning are not necessarily the same (Park, 2009). Although interconnected, informal and incidental learning are not necessarily the same. Incidental learning occurs as an unintended by-product of some other activity, such as learning skills from others, learning useful information at meetings, and encouraging other to express opinions in the meetings. The intention of the activity is task accomplishment, but increases particular knowledge, skills, or understanding. Although people are not always conscious of it, incidental learning takes place all the time.

The types of informal learning include on-the-job training, coaching, networking, mentoring, and sharing knowledge with others (Leslie, et al., 1998; Lohman, 2005; R. Rowden, 2007). According to Lohman (2005), informal workplace learning activities can be categorized into collaborating, talking with others, sharing materials and resources, searching the Internet, observing people, trial and error, and reflecting upon one's actions (Lohman, 2005).

\subsection{Formal Workplace Learning}

Formal learning can be defined as a planned learning activity in specific place with instructors or trainers and distinctive details usually outside the work (Mocker \& Spear, 1982). Generally, formal learning consists of "traditional classroombased training, web-based training, training in a corporate university, and tuition reimbursement” (R. L. Jacobs \& Park, 2009).

In this study, formal workplace learning is defined as a training program through several statements such as accessibility of job related training, availability of training funds, support for formal education, and support for training from top management.

\section{Workplace learning and Job performance}

Relationship between workplace learning and job performance can be described by periodic efforts at a task through the work process. Human learning systems can be described mathematically. The "learning curve" describes a relationship between job performance and practice, suggesting that enhancements will be better immediately after training sections, then increase in power with practice until performance stabilizes at a level of expertise (Park, 2009). There are several reasons for using Learning curves, such as comparing a difficulty between tasks and predicting successful training for improving task (Swezey \& Llaneras, 1997). Mathematical characterizations of learning curves give a set of parameters that clarify the curve, each of which requires insight into the learning process (Meador, 2008; Park, 2009).

One of the most famous assumptions in HRD is that "the primary outcome of HRD is not just learning but also performance"(R. A. Swanson \& E. F. Holton, 2001). This is because the dependent variable in HRD performance is individual and organizational performance, the focus of which is placed on the transfer of learning to job performance. According to Holton (2000), scholars are still working on the transfer of learning with operationalized organizational factors. Achieving learning outcomes reflects the transfer of learning from various influences (Baldwin \& Ford, 1988; Holton, 2002).

Many researchers have argued about importance of learning for improving job performance, claiming that it is not sufficient (Bates, Holton III, Seyler, \& Carvalho, 2000; Tracey, Tannenbaum, \& Kavanagh, 1995). The performance elements of HRD with learning help develop the expertise construct (Swanson \& Holton, 1999). Swanson and Holton (2001) defined expertise as "human behaviors, having effective results and optimal efficiency, acquired through study and experience within a specialized domain" (p. 26).

Literature on workplace learning studied learning outcomes as result of workplace learning, reporting various outcomes, such as skills and abilities, employees' work performance, motivation to transfer learning, knowledge, organizational performance, and organizational commitment (Dysvik \& Kuvaas, 2008; Enos, Kehrhahn, \& Bell, 2003; Lankau \& Scandura, 2002; Maurer, Lippstreu, \& Judge, 2008; Park, 2009; Tsai \& Tai, 2003; Velada, Caetano, Michel, Lyons, \& Kavanagh, 2007).

Another research that focused on the importance of informal learning rather than formal learning conducted by Marsick and Watkins (2001)showed that informal and incidental learning play a critical role in increasing employee's job satisfaction and job performance as well (R. W. Rowden \& Conine Jr, 2005).

Another research conducted by Hoffman and Mehra (1999) provided evidence for the relationship between workplace learning and performance. The sample was 100 managers of a medium size manufacturing company. They identified several critical issues, such as (1) unplanned approach for improving productivity; (2) weaknesses in supervisory training relate to productivity problem; (3) poor investment in employee training; (4) lack of communication; and (5) poor involvement and commitment of top management (Hoffman \& Mehra, 1999). Based on this research, it seems that training as formal learning is the key factor in performance improvement programs. 
The argument about learning and performance is crucial in human resource development studies. As Holton (2000) said, "I cannot imagine a life without learning, nor can I imagine one without performance. The challenge for the HRD profession is to ensure that neither one becomes a tool for oppression but rather elevates human potential" (Holton, 2000, p.64).

In the following sections, we explore each workplace learning type in relation to task and contextual performance. Workplace learning involves continuous interactions among formal, informal and incidental learning and provides a context for solving business problems and improving performance (S. Y. Moon \& S. I. Na, 2009).

\subsection{Informal Workplace Learning and Job Performance}

Informal workplace learning is defined as learning in a place of work where the employee experiences social interactions and relationship with colleagues and people in the workplace (Park, 2009; R. Rowden, 2007). Moreover, the term informal learning is described as learning through informal and frequently unplanned relationships characterized by a close contact being part of program (Poell, Van Dam, \& Van Den Berg, 2004). Similarly, Lohman (2005)defined informal learning as "an aspect of workplace learning that specifically involves those learning activities that employees initiate in the workplace, involve the expenditure of physical cognitive, or emotional effort, and result in the development of professional knowledge and skills" (p.502).

Informal learning programs contain or involve networking, mentoring, coaching, modeling and facilitation, interrelational characteristics of teams, and individual traits and abilities (Marsick \& Watkins, 1990). Employees use informal learning to achieve information or support, gain ability to give greater feedback, learn from alternative viewpoints, consider alternative ways to think and behave (planned or unplanned), "reflect on processes to assess learning experience outcomes and to make choices on where to focus their attention" (Marsick \& Watkins, 2001, p. 28).

Likewise, Garavan et al. (2004) wrote that workplace learning is "a set of processes, which occur within specific organizational contexts and focus on acquiring and assimilating an integrated cluster of knowledge, skills, values and feeling that results in individuals and teams refocusing and fundamentally changing their behavior" (p. 61). Accordingly, we propose the following hypotheses:

H1: There is a significant positive relationship between informal workplace learning and job performance.

H1a: There is a significant positive relationship between informal workplace learning and task performance.

H1b: There is a significant positive relationship between informal workplace learning and contextual performance.

\subsection{Incidental Workplace Learning and Job Performance}

Many researchers agree that the context plays an important part in shaping the incidental learning. Previous research distinguished socio-economic context from cultural context (Ellinger \& Cseh, 2007). Another aspect of context is the individual's workplace. Each job provides different types of training, different norms and mental models, different opportunities, and different priorities for learning.

Professionals are expected "to perform tasks for which they have not been educated;" therefore, the professional knowledge involves facing the new demands of professional practice; therefore, "the improvement in professional performance would be transitory" (Schön, 1983, pp 14-15). Hence, we propose the following hypotheses:

$\mathrm{H} 2$ : There is a significant positive relationship between incidental workplace learning and job performance.

H2a: There is a significant positive relationship between incidental workplace learning and task performance.

$\mathrm{H} 2 \mathrm{~b}$ : There is a significant positive relationship between incidental workplace learning and contextual performance.

\subsection{Formal Workplace Learning and Job Performance}

Swanson and Holton (2001) noted that "the majority of what people learn related to their work performance is not planned in the way training and development professionals have traditionally talked about work-related learning" (R. A. Swanson \& E. Holton, 2001,p.85).

Clarke (2005) discussed training programs that focused on technical skill learning to improve employee current job performance, suggesting that learning for everyday tasks in workplace looks to be unachievable through training (Park, 2009). Enos et al. (2003) argued that formal training cannot facilitate change in the workplace and does not support environmental interaction between managers and the real-world experience with an aim to develop job proficiency.

On-the-job training (OJT) is one of the well-known theories that explain the transfer of learning to job performance. OJT focuses on the skill and knowledge that employees need to improve through the continuous changes that they are facing every day in times of growing technology and competition. OJT can help employees achieve skill and knowledge necessary to complete certain tasks. One of the advantages of this approach can be learning new techniques and knowledge from the last training session and from doing job related tasks (Liu \& Batt, 2005). It seems more effective than the other types of training or classroom based training activities because employees learn within their work context. In other words, through OJT, organizations remove some problems that occur when employees try to transfer new techniques and skills in the own jobs (Liu \& Batt, 2005).

Some researchers examined the relationship of training as a formal workplace learning with other variables, such as employee involvement, job satisfaction (Aragon-Sanchez, Barba-Aragon, \& Sanz-Valle, 2003; Garcia-Morales, RuizMoreno, \& Llorens-Montes, 2007), nonfinancial organization performance, and financial organization performance (Park, 2009). They reported positive relationships of workplace learning with employee involvement and satisfaction. 
The research conducted by Aragón-Sánchez et al. (2003) examined the effects of training program on performance. They claimed that training has a positive relationship with performance. They concluded that organizations ignore the contribution of training to goal achievement and the effect of training on the effectiveness and profitability. In addition, different types of training activity have different effects on the effectiveness and the results of the training (AragonSanchez, et al., 2003). However, they did not address factors affecting on result of training. One question of whether the organizational factors affect the results of training remains unanswered. Which conditions cause the positive relationship between training and performance?

Tharenou, Saks and Moore (2007) found that training has a positive relationship with organizational performance and human resource outcomes. They discussed the effect of contextual factors on these outcomes trough the contingency perspective, such as business strategy and organizational capital intensity. However, in their study, they suggested that this relationship occurs at the organizational level (Tharenou, Saks, \& Moore, 2007). However, the study showed that the individual level could explain organizational performance problems better because individual performance determines organizational performance. Accordingly, we propose the following hypotheses:

H3: There is a significant positive relation between formal workplace learning and job performance.

H3a: There is a significant positive relationship between formal workplace learning and task performance.

H3b: There is a significant positive relationship between formal workplace learning and contextual performance.

\section{Conclusion}

This paper reviewed the existing literature on workplace learning and job performance. The paper identified three types of workplace learning that can improve task and contextual performance.

Based on previous research, it was hypothesized a positive direct significant relationships between workplace learning types and task performance and between workplace learning and contextual performance.

In the future, it is strongly encouraged that an empirical research is conducted to determine the relationship between workplace learning and job performance. It will not only theoretically contribute to the existing studies of the human resource development, but also practically instruct managers, supervisor and government officers on using the findings of the study to design appropriate learning and performance improvement interventions. The job can be structured in relation to workplace learning, which can improve job performance.

\section{References}

Aragon-Sanchez, A., Barba-Aragon, I., \& Sanz-Valle, R. (2003). Effects of training on business results. International Journal of Human Resource Management, 14(6), 956-980.

Baldwin, T. T., \& Ford, J. K. (1988). Transfer of training: A review and directions for future research. Personnel psychology, 41(1), 63-105.

Barrie, J., \& Wayne Pace, R. (1998). Learning for organizational effectiveness: Philosophy of education and human resource development. Human Resource Development Quarterly, 9(1), 39-54.

Bates, R. A., Holton III, E. F., Seyler, D. L., \& Carvalho, M. A. (2000). The role of interpersonal factors in the application of computer-based training in an industrial setting. Human Resource Development International, 3(1), 1942.

Bierema, L. L. (2000). Moving beyond performance paradigms in human resource development. Handbook of adult and continuing education, 278-293.

Billett, S. (2001). Learning through work: workplace affordances and individual engagement. Journal of Workplace Learning, 13(5), 209-214.

Borman, W. C., \& Brush, D. H. (1993). More progress toward a taxonomy of managerial performance requirements. Human performance, 6(1), 1-21.

Borman, W. C., Buck, D. E., Hanson, M. A., Motowidlo, S. J., Stark, S., \& Drasgow, F. (2001). An examination of the comparative reliability, validity, and accuracy of performance ratings made using computerized adaptive rating scales.

Journal of Applied Psychology, 86(5), 965.

Borman, W. C., \& Motowidlo, S. J. (1993). Expanding the criterion domain to include elements of contextual performance. Personnel selection in organizations, 71, 98.

Borman, W. C., \& Motowidlo, S. J. (1997). Task performance and contextual performance: The meaning for personnel selection research. Human Performance, 10(2), 99-109.

Borman, W. C., White, L. A., Pulakos, E. D., \& Oppler, S. H. (1991). Models of supervisory job performance ratings. Journal of Applied Psychology, 76(6), 863.

Brown, J. S., \& Duguid, P. (1991). Organizational learning and communities-of-practice: Toward a unified view of working, learning, and innovation. Organization science, 40-57.

Campbell, J. P., McCloy, R. A., Oppler, S. H., \& Sager, C. E. (1993). A theory of performance. Personnel selection in organizations, 3570 .

Campbell, J. P., McHenry, J. J., \& Wise, L. L. (1990). Modeling job performance in a population of jobs. Personnel Psychology, 43(2), 313-575.

Clarke, N. (2005). Workplace learning environment and its relationship with learning outcomes in healthcare organizations. Human Resource Development International, 8(2), 185-205. 
Coleman, V. I., \& Borman, W. C. (2000). Investigating the underlying structure of the citizenship performance domain. Human Resource Management Review, 10(1), 25-44.

Colley, H., Hodkinson, P., \& Malcom, J. (2003). Informality and formality in learning: a report for the Learning and Skills Research Centre (Report). London: Learning and Skills Research Centre.

Cromwell, S. E., \& Kolb, J. A. (2004). An examination of workplace environment support factors affecting transfer of supervisory skills training to the workplace. Human Resource Development Quarterly, 15(4), 449-471.

Dysvik, A., \& Kuvaas, B. (2008). The relationship between perceived training opportunities, work motivation and employee outcomes. International Journal of Training and Development, 12(3), 138-157.

Ellinger, A. D., \& Cseh, M. (2007). Contextual factors influencing the facilitation of others' learning through everyday work experiences. Journal of Workplace Learning, 19(7), 435-452.

Enos, M. D., Kehrhahn, M. T., \& Bell, A. (2003). Informal learning and the transfer of learning: How managers develop proficiency. Human Resource Development Quarterly, 14(4), 369-387.

Garavan, T. N., McGuire, D., \& O’Donnell, D. (2004). Exploring human resource development: A levels of analysis approach. Human Resource Development Review, 3(4), 417.

Garcia-Morales, V. J., Ruiz-Moreno, A., \& Llorens-Montes, F. J. (2007). Effects of technology absorptive capacity and technology proactivity on organizational learning, innovation and performance: an empirical examination. Technology Analysis \& Strategic Management, 19(4), 527-558.

George, J. M., \& Brief, A. P. (1992). Feeling good-doing good: a conceptual analysis of the mood at workorganizational spontaneity relationship. Psychological Bulletin, 112(2), 310.

Gilbert, T. F. (1978). Human competence-Engineering worthy performance. NSPI journal, 17(9), 19-27.

Harrison, D. A., Newman, D. A., \& Roth, P. L. (2006). How Important Are Job Attitudes? Meta-Analytic Comparisons of Integrative Behavioral Outcomes and Time Sequences. Academy of Management journal, 49(2), 305-325. Heilmann, P. (2007). High level competence: a tool for coping with organizational change. Journal of European Industrial Training, 31(9), 727-741.

Hoffman, J. M., \& Mehra, S. (1999). Management leadership and productivity improvement programs. International Journal of Applied Quality Management, 2(2), 221-232.

Holton, E. F. (2000). On the nature of performance and learning in human resource development. Advances in Developing Human Resources, 2(3), 60.

Holton, E. F. (2002). Theoretical assumptions underlying the performance paradigm of human resource development. Human Resource Development International, 5(2), 199-215.

Hunter, J. E. (1986). Cognitive ability, cognitive aptitudes, job knowledge, and job performance. Journal of Vocational Behavior, 29(3), 340-362.

Illeris, K. (2004). A model for learning in working life. Journal of Workplace Learning, 16(8), 431-441.

Jacobs, R., \& Washington, C. (2003). Employee development and organizational performance: a review of literature and directions for future research. Human Resource Development International, 6(3), 343-354.

Jacobs, R. L., \& Park, Y. (2009). A proposed conceptual framework of workplace learning: Implications for theory development and research in human resource development. Human Resource Development Review, 8(2), 133.

Jones, M. D. (2006). Which is a better predictor of job performance: Job satisfaction or life satisfaction. Journal of Behavioral and Applied Management, 8(1), 20-42.

Katz, D., \& Kahn, R. L. (1978). The social psychology of organizations.

Kyndt, E., Dochy, F., Michielsen, M., \& Moeyaert, B. (2009). Employee retention: organisational and personal perspectives. Vocations and Learning, 2(3), 195-215.

Lankau, M. J., \& Scandura, T. A. (2002). An investigation of personal learning in mentoring relationships: Content, antecedents, and consequences. Academy of management Journal, 779-790.

Leslie, B., Aring, M. K., \& Brand, B. (1998). Informal learning: The new frontier of employee \& organizational development. Economic Development Review, 15, 12-18.

Liu, X., \& Batt, R. (2005). The economic pay-offs to on-the-Job training in routine service Work.

Lohman, M. C. (2005). A survey of factors influencing the engagement of two professional groups in informal workplace learning activities. Human Resource Development Quarterly, 16(4), 501-527.

Marsick, V. J. (1987). Learning in the workplace: Croom Helm Ltd.

Marsick, V. J., \& Watkins, K. E. (1990). Informal and incidental learning in the workplace: Routledge London. Marsick, V. J., \& Watkins, K. E. (2001). Informal and incidental learning. New directions for adult and continuing education, 2001(89), 25-34.

Matthews, P. (1999). Workplace learning: developing an holistic model. Learning Organization, The, 6(1), 18-29.

Maurer, T. J., Lippstreu, M., \& Judge, T. A. (2008). Structural model of employee involvement in skill development activity: The role of individual differences. Journal of Vocational Behavior, 72(3), 336-350.

Meador, D. P. (2008). Modeling training effects on task performance using a human performance taxonomy. Wright State University, Fairborn, Ohio.

Mocker, D. W., \& Spear, G. E. (1982). Lifelong Learning: Formal, Nonformal, Informal, and Self-Directed. Information Series No. 241.

Moon, S.-Y., \& Na, S.-I. (2009). Psychological and organizational variables associated with workplace learning in small and medium manufacturing businesses in Korea. Asia Pacific Education Review, 10(3), 327-336.

Moon, S. Y., \& Na, S. I. (2009). Psychological and organizational variables associated with workplace learning in small and medium manufacturing businesses in Korea. Asia Pacific Education Review, 10(3), 327-336. 
Motowidlo, S. J. (2003). Job performance. Handbook of psychology.

Motowildo, S. J., Borman, W. C., \& Schmit, M. J. (1997). A theory of individual differences in task and contextual performance. Human performance, 10(2), 71-83.

Murphy, K. R., \& Shiarella, A. H. (1997). Implications of the multidimensional nature of job performance for the validity of selection tests: Multivariate frameworks for studying test validity. Personnel Psychology, 50(4), 823-854. Organ, D. W. (1988). Organizational citizenship behavior: The good soldier syndrome: Lexington Books/DC Heath and Com.

Organ, D. W., Podsakoff, P. M., \& MacKenzie, S. B. (2006). Organizational citizenship behavior: Its nature, antecedents, and consequences: Sage Publications, Inc.

Park, Y. (2009). The relationships among investment in workplace learning, organizational perspective on human resource development, organizational outcomes of workplace learning, and organizational performance using the Korea 2005 and 2007 Human Capital Corporate Panel surveys. The Ohio State University.

Patterson, M. G., West, M. A., Shackleton, V. J., Dawson, J. F., Lawthom, R., Maitlis, S., et al. (2005). Validating the organizational climate measure: links to managerial practices, productivity and innovation. Journal of organizational behavior, 26(4), 379-408.

Poell, R. F., Van Dam, K., \& Van Den Berg, P. T. (2004). Organising learning in work contexts. Applied Psychology, 53(4), 529-540.

Reio Jr, T. G. (1997). Effects of curiosity on socialization-related learning and job performance in adults. Virginia Polytechnic Institute and State University.

Rothwell, W. J. (2002). The workplace learner: How to align training initiatives with individual learning competencies: AMACOM/American Management Association.

Rotundo, M., \& Sackett, P. R. (2002). The relative importance of task, citizenship, and counterproductive performance to global ratings of job performance: a policy-capturing approach. Journal of Applied Psychology, 87(1), 66.

Rowden, R. (2007). Workplace learning principles and practice: Malabar, FL: Krieger Publishing Company.

Rowden, R. W. (2002). The relationship between workplace learning and job satisfaction in US small to midsize businesses. Human Resource Development Quarterly, 13(4), 407-425.

Rowden, R. W., \& Conine Jr, C. T. (2005). The impact of workplace learning on job satisfaction in small US commercial banks. Journal of Workplace Learning, 17(4), 215-230.

Schmidt, F. L., Hunter, J. E., Outerbridge, A. N., \& Goff, S. (1988). Joint relation of experience and ability with job performance: Test of three hypotheses. Journal of Applied Psychology; Journal of Applied Psychology, 73(1), 46. Schön, D. A. (1983). The reflective practitioner: How professionals think in action (Vol. 5126): Basic books. Smith, A., \& Hayton, G. (1999). What drives enterprise training? Evidence from Australia. International Journal of Human Resource Management, 10(2), 251-272.

Sonnentag, S., \& Frese, M. (2002). Performance concepts and performance theory. Psychological management of individual performance, 23, 3-25.

Swanson, R. A., \& Holton, E. (2001). Foundations of human resource management. San Francisco, CA: BerrettKoehler Publishers.

Swanson, R. A., \& Holton, E. F. (1999). Results: How to Assess Performance, Learning, \& Perceptions in Organizations: Berrett-Koehler Publishers.

Swanson, R. A., \& Holton, E. F. (2001). Foundations of human resource development (3rd ed.). San Francisco: BerrettKoehler.

Swezey, R. W., \& Llaneras, R. E. (1997). Models in training and instruction. Handbook of human factors and ergonomics, 514-577.

Tharenou, P., Saks, A. M., \& Moore, C. (2007). A review and critique of research on training and organizational-level outcomes. Human Resource Management Review, 17(3), 251-273.

Tracey, J. B., Tannenbaum, S. I., \& Kavanagh, M. J. (1995). Applying trained skills on the job: The importance of the work environment. Journal of Applied Psychology, 80(2), 239.

Tsai, W. C., \& Tai, W. T. (2003). Perceived importance as a mediator of the relationship between training assignment and training motivation. Personnel Review, 32(2), 151-163.

Van Dyne, L., \& LePine, J. A. (1998). Helping and voice extra-role behaviors: Evidence of construct and predictive validity. Academy of Management journal, 41(1), 108-119.

Velada, R., Caetano, A., Michel, J. W., Lyons, B. D., \& Kavanagh, M. J. (2007). The effects of training design, individual characteristics and work environment on transfer of training. International Journal of Training and Development, 11(4), 282-294.

Watkins, K. E., \& Marsick, V. J. (1992). Towards a theory of informal and incidental learning in organizationsâ^—. International journal of lifelong education, 11(4), 287-300.

Welbourne, T. M., Johnson, D. E., \& Erez, A. (1998). The role-based performance scale: Validity analysis of a theory based measure. Academy of Management journal, 41(5), 540-555. 